\title{
Age of Appearance of Diabetes Autoantibodies in Type 1a Diabetics and Their Siblings in Côte D'ivoire
}

\author{
Trébissou Aïssé Florence Judith ${ }^{1,2, *}$, Sanogo Mamadou ${ }^{3}$, Sibailly Pascal ${ }^{4}$, Ankotché Amos ${ }^{4}$, \\ Lokrou Adrian ${ }^{3}$, Hatem Masmoudi ${ }^{5}$, Yapo Adou Francis ${ }^{1}$, Djaman Allico Joseph ${ }^{1,6}$ \\ ${ }^{1}$ Laboratory of Biochemistry-Pharmacodynamics, Faculty of Biosciences, Felix Houphouët Boigny University, Cote d'Ivoire \\ ${ }^{2}$ National Institute of Public Health, Abidjan, Côte d'Ivoire \\ ${ }^{3}$ Diabetology and Endocrinology Department, University Hospital Center (U.H.C) of Yopougon, Côte d'Ivoire \\ ${ }^{4}$ Diabetes Clinic, University Hospital Center (U.H.C) of Treichville, Côte d'Ivoire \\ ${ }^{5}$ Laboratory of Immunology, Hospital Habib Bourguiba of Sfax, Tunisia \\ ${ }^{6}$ Department of Medical Biochemistry and Fundamental, Pasteur Institute of Côte d'Ivoire, Côte d'Ivoire
}

Copyright $\bigcirc 2018$ by authors, all rights reserved. Authors agree that this article remains permanently open access under the terms of the Creative Commons Attribution License 4.0 International License

\begin{abstract}
Diabetes autoantibodies, which are important markers of classification and prevention of type 1 diabetes, are absent in the diabetes care in Côte d'Ivoire. The study aim was to determine the age at which these autoantibodies were at their highest levels in type 1A diabetic patients (T1D) and their siblings in Côte d'Ivoire. The study population is composed of 28 T1D patients and 59 siblings, aged from 5 to 21 years. T1D were followed up in the U.H.C Endocrinology departments of Yopougon and Treichville, in the District of Abidjan. Anti-GAD and anti-IA2 autoantibodies were researched by ELISA and anti-ICA autoantibodies by indirect immunofluorescence on monkey pancreas. The peaks of anti-GAD and anti-IA2 autoantibodies were observed respectively at 9 years old $(604.30 \pm 521.70 \mathrm{IU} / \mathrm{ml})$ and 10 years old $(125.10 \pm 90.10$ $\mathrm{IU} / \mathrm{ml}$ ) in T1D. In siblings, the peaks of anti-GAD and anti-IA2 autoantibodies were observed respectively at 13 years old $(137 \mathrm{IU} / \mathrm{ml})$ and 10 years old $(53 \pm 40 \mathrm{IU} / \mathrm{ml})$. The peak of diabetes autoantibodies in T1D and their siblings in Côte d'Ivoire is at a very young age noted. This could explain the high mortality rate among T1D youth in Côte d'Ivoire.
\end{abstract}

Keyswords Diabetes Autoantibodies, Type 1A Diabetes, Age of Peak of Autoantibodies, Côte d'Ivoire

\section{Introduction}

Type $1 \mathrm{~A}$ diabetes or juvenile insulin-dependent diabetes is a disease that affects more than 31 million people worldwide [1]. In Africa, 39,100 children aged from 0 - to 14 years have type $1 \mathrm{~A}$ diabetes in 2013 [2] and $0.4 \%$ of children and adolescents in Côte d'Ivoire [3]. Type 1A diabetes is an autoimmune disease, the final consequence of a slow and gradual process of pancreatic islet Langerhans cells leading $\beta$ cells destruction, in the absence of treatment, to ketoacidosis [4]. $\beta$ cells destruction affects insulin production, and begins the initiation of the autoimmune reaction triggered by certain environmental factors and, after several years of evolution, leads to the clinical signs of the disease when the mass of $\beta$ cells becomes insufficient to regulate blood glucose [5]. Thus, the development of the autoimmune reaction, characterized by the progressive infiltration of Langerhans islets, would be carried out without destruction of the $\beta$ cells. Subsequently, under the effect of a hypothetical environmental triggering factor, the effectors responsible for the destruction of these $\beta$ cells would be established. During this longer or shorter period, which can be defined as a pre-diabetic stage, certain signs indicative of $\beta$-cell lesion can already be demonstrated, in particular anti-pancreas autoantibodies [6]. Type 1A diabetes or juvenile insulin-dependent diabetes is a major public health problem due to the often early onset of the disease, increasing incidence in most populations, lack of curative treatment and vascular complications related to residual hyperglycemia despite insulin injections in treated patients [7]. It is an incurable disease that is gaining momentum in Africa and particularly in Côte d'Ivoire. Today, the diagnosis of type $1 \mathrm{~A}$ diabetes is biological (fasting glucose greater than $1.26 \mathrm{~g} \mathrm{/} \mathrm{l)} \mathrm{and} \mathrm{requires} \mathrm{the} \mathrm{search} \mathrm{for}$ autoantibodies of diabetes as a confirmation marker for autoimmune process [8-10]. According to several authors, these autoantibodies of diabetes are present in siblings of type 1A diabetics (T1D) and are markers of the imminence of diabetes in this population at risk [11-13]. In Côte d'Ivoire, there is an absence of diagnosis of diabetes autoantibodies in the diabetes care, resulting in incomplete 
care. The search for autoantibodies is essential in the prevention of type 1A diabetes in the siblings of patients, but also in the classification of diabetics, some of whom are taken as type 2 diabetics when they are actually type $1 \mathrm{~A}$. It is therefore important to diagnose diabetes as early as possible in order to avoid the rapid evolution of the disease and its aggravation in the long term. The aim of this work is to show the presence of diabetes autoantibodies in T1D and their siblings and to determine the peak of these autoantibodies in T1D and their siblings aged from 5 to 21 years in Côte d'Ivoire.

\section{Material and Methods}

\section{Material}

\section{Study Population}

The study population was composed of 87 people. It included 28 known T1D patients aged from 5 to 21 years and followed up in two diabetes care centers in Abidjan district, Côte d'Ivoire. The Endocrinology department of the University Hospital Center (U.H.C) of Yopougon and the Diabetes Clinic of U.H.C of Treichville. Some T1D have been recruited from two NGOs, the Diabetics Association of Côte d'Ivoire (DIACI) and the New Diabetic Association of Côte d'Ivoire (NDIACI). The study population was also composed of 59 apparently healthy consanguineous siblings of the selected T1D patients, also aged from 5 to 21 years. The sex ratio of the whole study population (28 patients and 59 healthy controls) was 0.89 (41 boys and 46 girls); the mean age of T1D was $12.62 \pm$ 2.75 years and that of diabetic siblings was $12.13 \pm 4.94$ years. This cross-sectional study started in January 2014 and ended in April 2016.

\section{Selection criteria}

1. Inclusion criteria

The T1D selected were aged from 5 to 21 years and declared diabetics between 2007 and 2016. They had at least one non-diabetic sibling aged from 5 to 21 and a complete medical folder of T1D.

\section{Non-inclusion criteria}

HIV-positive patients undergoing antiretroviral therapy were excluded from the study because of the impact of ARVs that would lead to hyperglycemia.

\section{Biological Material}

The biological material was composed essentially of serum. These sera were obtained after centrifugation at $3000 \mathrm{rpm}$ for 3 minutes of venus blood collected on dry tubes in T1D and their siblings.

\section{Methods}

\section{Selection of Type 1A Diabetics and Their Siblings}

The project was approved by the ethics committee of Pasteur Institute of Côte d'Ivoire. It consisted in selecting T1D in Yopougon and Treichville U.H.C as well as NOGs, DIACI and NDIACI. Folders of T1D aged from 5 to 21 years were selected. The year of screening for diabetes was between 2007 and 2016. The contacts of the parents of each patient (telephone, PO BOX and email) were identified and each parent of the patients was then contacted by telephone. During the conversations, they were told about the benefit of the study, which was to make early detection of type $1 \mathrm{~A}$ diabetes in their families, to prevent other coming years cases in their family. It was asked after a good understanding to each parent, the existence or not of siblings of the diabetic child aged from 5 to 21 years. T1D who met these conditions were selected. The parents were invited with their children in the different U.H.C for sampling. On the site, parents were invited to sign informed consent cards. They were then offered a consent form for the child's consent and a survey containing clinical information for diabetics on the one hand and for siblings on the other hand. For the illiterate parents, the consent has been materialized by a borrowing of the right index finger in the presence of a witness who also has given this agreement by signature of the same form.

\section{Search of Anti-islet Cells Autoantibodies}

This research is done by indirect immunofluorescence on monkey pancreas using a commercial kit (Euroimmun ${ }^{\circledR}$, Germany). Sections of monkey pancreas are incubated with the patient's diluted serum. The reaction is positive if the IgA, IgG and IgM class-specific antibodies bind to the $\beta$-cells of the Langerhans islets of the monkey pancreas. In the second step, fluorescein-labeled anti-human IgG antibodies bind to the antibody-antigen complex for fluorescence microscopy detection [14-16].

\section{Search of Anti-glutamic Acid Decarboxylase Autoantibodies and Anti-tyrosine Phosphatase IA2 Autoantibodies}

The dosage of these two autoantibodies is done by ELISA method. The anti-GAD ELISA is a quantitative in vitro assay for GADA. Patient serum is incubated with GAD coated onto a microplate. If sample is positive, specific autoantibodies bind to the GAD. Bound antibodies are able to act divalenty and form a bridge between GAD on microplate well and biotin-labeled GAD, which is added in a second incubation step. To detect the bound biotin, a third incubation is carried out using enzyme-labeled avidin, which is capable of promoting a color reaction. The intensity of the color formed is proportional to the antibody against GAD. 
The anti-IA2 ELISA is a quantitative in vitro assay for IA2A. Patient serum is incubated with IA2 coated onto a microplate. If sample is positive, specific autoantibodies bind to the IA2. Bound antibodies are able to act divalenty and form a bridge between IA2 on microplate well and biotin-labeled IA2, which is added in a second incubation step. To detect the bound biotin, a third incubation is carried out using enzyme-labeled avidin, which is capable of promoting a color reaction. The intensity of the color formed is proportional to the antibody against IA2 [8, 17-19].

\section{Statistical Analysis}

Statistical analysis of the data was done with the GraphPad Prism.V5.01 software. The Student's t-test allowed statistical analysis of the means between T1D and their siblings. The difference between two variances was significant if $\mathrm{p}<0.05$.

\section{Results}

The anti-islet cells antibodies (anti-ICA) were present in 1/28 T1D (F16A) and absent in siblings, diagnosed in 2014. Anti-glutamic acid decarboxylase autoantibodies (anti-GAD) were present in 16/28 T1D patients $(57.14 \%)$ and 2/59 in siblings (F13B and F25C) (3.39\%) (Table 1). The mean value of anti-GAD autoantibodies in T1D was $448.3 \pm 126.5 \mathrm{IU} / \mathrm{ml}$ and $128.5 \pm 8.50 \mathrm{IU} / \mathrm{ml}$ in siblings $(\mathrm{p}<0.0001)$. It should be noted that anti-phosphatase autoantibodies (anti-IA2) were present in 13/28 T1D $(46.43 \%)$ and $10 / 59$ in siblings $(16.95 \%)$ (Table 1$)$. The mean value of IA2 autoantibodies in T1D was $114.2 \pm$ $37.42 \mathrm{IU} / \mathrm{ml}$ and $33.17 \pm 9.6 \mathrm{IU} / \mathrm{ml}$ in siblings $(\mathrm{p}$ $=0.0021<0.05$ ). 
Table 1. Age, autoantibodies anti-islet cells, anti-GAD and anti-IA2 in type $1 \mathrm{~A}$ diabetics and their siblings

\begin{tabular}{|c|c|c|c|c|c|}
\hline Type 1A Diabetics & Identification & $\begin{array}{c}\text { Age and sex } \\
\text { of patient }\end{array}$ & $\begin{array}{l}\text { Anti-Islet Cells (indirect } \\
\text { immunofluorescence) }\end{array}$ & $\begin{array}{c}\text { Anti-GAD } \\
\text { (ELISA) (UI/ml) }\end{array}$ & $\begin{array}{c}\text { Anti-IA2 (ELISA) } \\
\text { (UI/ml) }\end{array}$ \\
\hline 1 & F1A & 14 ans / M & Négative & 0 & 0 \\
\hline 2 & $\mathrm{~F} 2 \mathrm{~A}$ & 10 ans / F & Négative & 0 & 24.6 \\
\hline 3 & F3A & 12 ans / F & Négative & 0 & 0 \\
\hline 4 & $\mathrm{~F} 4 \mathrm{~A}$ & 15 ans / $M$ & Négative & 0 & 0 \\
\hline 5 & F5A & 18 ans / F & Négative & 117 & 0 \\
\hline 6 & F6A & 12 ans / F & Négative & 52.9 & 33.2 \\
\hline 7 & F7A & 9 ans / M & Négative & 82.6 & 112 \\
\hline 8 & F8A & 13 ans / $\mathrm{M}$ & Négative & 0 & 0 \\
\hline 9 & F9A & 15 ans / $M$ & Négative & 101 & 0 \\
\hline 10 & F10A & 9 ans / M & Négative & 1126 & 0 \\
\hline 11 & F11A & 18 ans / $\mathrm{M}$ & Négative & 0 & 119 \\
\hline 12 & F12A & 13 ans / F & Négative & 0 & 0 \\
\hline 13 & F13A & 12 ans / F & Négative & 1139 & 38.4 \\
\hline 14 & F14A & 18 ans / $\mathrm{M}$ & Négative & 10.4 & 55.1 \\
\hline 15 & $\mathrm{~F} 15 \mathrm{~A}$ & 10 ans / $\mathrm{M}$ & Négative & 36.7 & 11.9 \\
\hline 16 & F16A & 10 ans / F & Positive & 1432 & 464 \\
\hline 17 & F17A & 11 ans / F & Négative & 0 & 0 \\
\hline 18 & F18A & 17 ans / $\mathrm{M}$ & Négative & 97,5 & 0 \\
\hline 19 & F19A & 14 ans / F & Négative & 785 & 16.4 \\
\hline 20 & F20A & 11 ans / $\mathrm{M}$ & Négative & 0 & 321 \\
\hline 21 & F21A & 14 ans / F & Négative & 113.2 & 164.5 \\
\hline 22 & F22A & 10 ans / F & Négative & 541,2 & 0 \\
\hline 23 & F23A & 13 ans / $\mathrm{M}$ & Négative & 0 & 0 \\
\hline 24 & F24A & 13 ans / F & Négative & 0 & 0 \\
\hline 25 & F25A & 12 ans / F & Négative & 1128 & 36.2 \\
\hline 26 & F26A & 11 ans $/ F$ & Négative & 0 & 0 \\
\hline 27 & F27A & 12 ans / F & Négative & 458 & 89 \\
\hline 28 & F28A & 15 ans / M & Négative & 25.6 & 0 \\
\hline \multicolumn{6}{|c|}{ Siblings } \\
\hline \multirow{3}{*}{1} & F1B & 10 ans $/ \mathrm{M}$ & Négative & 0 & 0 \\
\hline & $\mathrm{F} 1 \mathrm{C}$ & 9 ans / F & Négative & 0 & 0 \\
\hline & F1D & 21 ans / F & Négative & 0 & 0 \\
\hline \multirow{2}{*}{2} & F2B & 15 ans / F & Négative & 0 & 10.7 \\
\hline & $\mathrm{F} 2 \mathrm{C}$ & 9 ans / $M$ & Négative & 0 & 0 \\
\hline \multirow{2}{*}{3} & F3B & 12 ans / F & Négative & 0 & 0 \\
\hline & F3C & 13 ans / M & Négative & 0 & 42.6 \\
\hline \multirow{2}{*}{4} & F4B & 12 ans /F & Négative & 0 & 0 \\
\hline & $\mathrm{F} 4 \mathrm{C}$ & 9 ans / F & Négative & 0 & 0 \\
\hline 5 & F5B & 11 ans / F & Négative & 0 & 0 \\
\hline \multirow{2}{*}{6} & F6B & 17 ans /F & Négative & 0 & 0 \\
\hline & F6C & 12 ans / F & Négative & 0 & 0 \\
\hline \multirow{2}{*}{7} & F7B & 21 ans / M & Négative & 0 & 0 \\
\hline & $\mathrm{F} 7 \mathrm{C}$ & 15 ans / F & Négative & 0 & 10.8 \\
\hline
\end{tabular}

$\mathrm{F} 1 \mathrm{~A}=$ type $1 \mathrm{~A}$ diabetic of family $1 ; \mathrm{F} 1 \mathrm{~B}, \mathrm{C}, \mathrm{D}=$ siblings of type $1 \mathrm{~A}$ diabetics; $<10 \mathrm{IU} / \mathrm{ml}=$ négative, $\geq 10 \mathrm{IU} / \mathrm{ml}=$ positive 
Table 1 (after)

\begin{tabular}{|c|c|c|c|c|c|}
\hline Siblings & Identification & Age and sex of patient & $\begin{array}{l}\text { Anti-Islet Cells (indirect } \\
\text { immunofluorescence) }\end{array}$ & $\begin{array}{c}\text { Anti-GAD } \\
\text { (ELISA) (UI/ml) }\end{array}$ & $\begin{array}{c}\text { Anti-IA2 (ELISA) } \\
(\mathrm{UI} / \mathrm{ml})\end{array}$ \\
\hline \multirow{2}{*}{8} & F8B & 11 ans $/ F$ & Négative & 0 & 0 \\
\hline & $\mathrm{F} 8 \mathrm{C}$ & 9 ans $/ \mathrm{M}$ & Négative & 0 & 0 \\
\hline \multirow{2}{*}{9} & F9B & 21 ans / F & Négative & 0 & 0 \\
\hline & F9C & 11 ans / $\mathrm{M}$ & Négative & 0 & 0 \\
\hline \multirow{2}{*}{10} & F10B & 12 ans / F & Négative & 0 & 0 \\
\hline & F10C & 21 ans $/ F$ & Négative & 0 & 0 \\
\hline \multirow{2}{*}{11} & F11B & 16 ans / $M$ & Négative & 0 & 0 \\
\hline & F11C & 11 ans / F & Négative & 0 & 0 \\
\hline \multirow{2}{*}{12} & F12B & 10 ans $/ \mathrm{M}$ & Négative & 0 & 106 \\
\hline & $\mathrm{F} 12 \mathrm{C}$ & 12 ans / F & Négative & 0 & 0 \\
\hline \multirow{2}{*}{13} & F13B & 5 ans / $M$ & Négative & 120 & 12.4 \\
\hline & $\mathrm{F} 13 \mathrm{C}$ & 11 ans / F & Négative & 0 & 0 \\
\hline \multirow{2}{*}{14} & F14B & 14 ans / M & Négative & 0 & 0 \\
\hline & $\mathrm{F} 14 \mathrm{C}$ & 13 ans / F & Négative & 0 & 0 \\
\hline \multirow{2}{*}{15} & F15B & 9 ans $/ \mathrm{M}$ & Négative & 0 & 0 \\
\hline & $\mathrm{F} 15 \mathrm{C}$ & 14 ans / M & Négative & 0 & 0 \\
\hline \multirow{2}{*}{16} & F16B & 8 ans $/ F$ & Négative & 0 & 0 \\
\hline & F16C & 13 ans $/ F$ & Négative & 0 & 0 \\
\hline \multirow{2}{*}{17} & F17B & 8 ans / $M$ & Négative & 0 & 0 \\
\hline & F17C & 14 ans / F & Négative & 0 & 0 \\
\hline \multirow{2}{*}{18} & F18B & 12 ans / F & Négative & 0 & 0 \\
\hline & $\mathrm{F} 18 \mathrm{C}$ & 8 ans / F & Négative & 0 & 0 \\
\hline \multirow{3}{*}{19} & F19B & 18 ans $/ F$ & Négative & 0 & 0 \\
\hline & F19C & 11 ans / M & Négative & 0 & 0 \\
\hline & F19D & 5 ans / F & Négative & 0 & 0 \\
\hline \multirow{2}{*}{20} & F20B & 12 ans $/ \mathrm{M}$ & Négative & 0 & 0 \\
\hline & F20C & 13 ans / F & Négative & 0 & 32.8 \\
\hline \multirow{2}{*}{21} & F21B & 15 ans $/ \mathrm{M}$ & Négative & 0 & 18.7 \\
\hline & F21C & 8 ans $/ F$ & Négative & 0 & 0 \\
\hline \multirow{2}{*}{22} & F22B & 16 ans $/ \mathrm{M}$ & Négative & 0 & 0 \\
\hline & $\mathrm{F} 22 \mathrm{C}$ & $13 \mathrm{ans} / \mathrm{M}$ & Négative & 0 & 0 \\
\hline \multirow{3}{*}{23} & F23B & 7 ans / F & Négative & 0 & 0 \\
\hline & $\mathrm{F} 23 \mathrm{C}$ & 17 ans/ $\mathrm{M}$ & Négative & 0 & 0 \\
\hline & F23D & 18 ans / $\mathrm{M}$ & Négative & 0 & 0 \\
\hline \multirow{2}{*}{24} & F24B & 8 ans / $M$ & Négative & 0 & 0 \\
\hline & $\mathrm{F} 24 \mathrm{C}$ & 11 ans $/ \mathrm{M}$ & Négative & 0 & 0 \\
\hline \multirow{2}{*}{25} & F25B & 15 ans $/ M$ & Négative & 0 & 0 \\
\hline & $\mathrm{F} 25 \mathrm{C}$ & 13 ans / F & Négative & 137 & 61 \\
\hline \multirow{3}{*}{26} & F26B & 14 ans $/ \mathrm{M}$ & Négative & 0 & 0 \\
\hline & F26C & 21 ans $/ \mathrm{M}$ & Négative & 0 & 0 \\
\hline & F26D & 5 ans $/ \mathrm{F}$ & Négative & 0 & 13.2 \\
\hline \multirow{2}{*}{27} & F27B & 11 ans / $\mathrm{M}$ & Négative & 0 & 0 \\
\hline & F27C & 14 ans $/ \mathrm{M}$ & Négative & 0 & 0 \\
\hline \multirow{2}{*}{28} & F28B & 13 ans / F & Négative & 0 & 23.7 \\
\hline & $\mathrm{F} 28 \mathrm{C}$ & 17 ans / $\mathrm{M}$ & Négative & 0 & 0 \\
\hline
\end{tabular}

F1B, $\mathrm{C}, \mathrm{D}=$ siblings of type $1 \mathrm{~A}$ diabetics; $<10 \mathrm{IU} / \mathrm{ml}=$ négative, $\geq 10 \mathrm{IU} / \mathrm{ml}=$ positive 
Fig.1A showed the titer of anti-GAD autoantibodies according to T1D age. Indeed, the peak of anti-GAD autoantibodies in T1D in Côte d'Ivoire was observed at the age of 9 years with a maximum value of $604.30 \pm 521.70$ $\mathrm{IU} / \mathrm{ml}$. Then, a decrease in the values of the anti-GAD autoantibodies was observed in T1D at the age of 10 years, 12 years and 14 years $(502.50 \pm 333.50,352.60 \pm 212.20$, $301.00 \pm 245) \mathrm{IU} / \mathrm{ml}$, followed a fall in these values at 15 years, 17 years and 18 years $(42.20 \pm 30.31,97.50 \pm 00$, $10.40 \pm 00) \mathrm{IU} / \mathrm{ml}$ (Figure 1A).

Fig. 1B showed the titer of anti-IA2 autoantibodies according to T1D age. At the age of 9 years, the titer of anti-IA2 autoantibodies in T1D was $56 \pm 50 \mathrm{IU} / \mathrm{ml}$, then a peak of these anti-IA2 autoantibodies was observed at the age of 10 years with a maximum value of $125.10 \pm 90.10$ $\mathrm{IU} / \mathrm{ml}$. At 12, 14 and 18 years old, a decrease of the values of anti-IA2 autoantibodies was observed with respective titers of $49.20 \pm 13.31 \mathrm{IU} / \mathrm{ml}, 60.30 \pm 52.31 \mathrm{IU} / \mathrm{ml}$ and $58.03 \pm 34.38 \mathrm{IU} / \mathrm{ml}$ (Figure 1B).

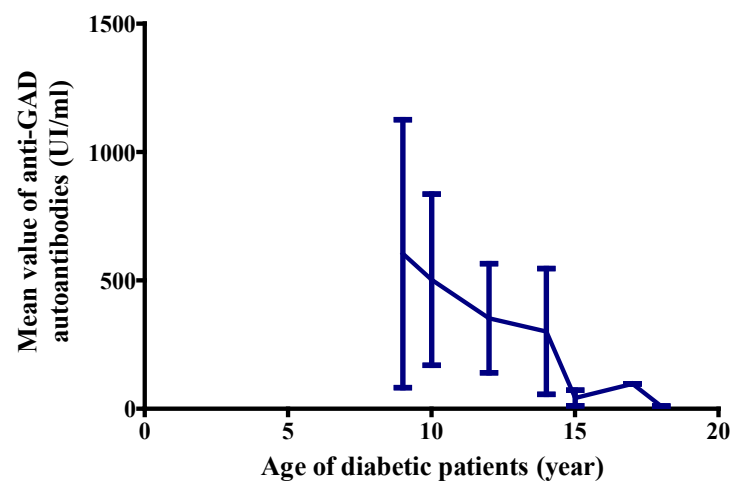

A

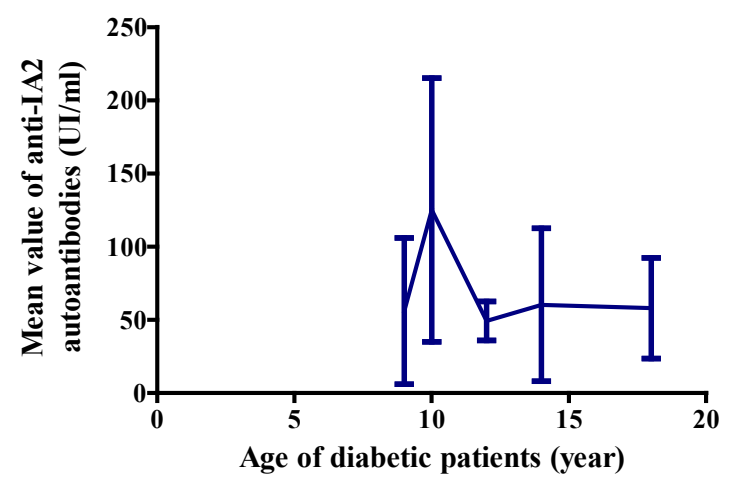

B

Figure 1. (Part A and Part B): Mean value of anti-GAD and anti-IA2 autoantibodies according to the age of type $1 \mathrm{~A}$ diabetics patients

In siblings of T1D, the titer of anti-GAD autoantibodies at 5 years old was $120 \mathrm{IU} / \mathrm{ml}$. The peak was observed at 13 years old with a maximum value of $137 \mathrm{IU} / \mathrm{ml}$ (Figure 2A).

At 5 years old, the titer of anti-IA2 autoantibodies in siblings of T1D was $11.60 \pm 4.27 \mathrm{IU} / \mathrm{ml}$, then a peak of these autoantibodies was observed at the age of 10 years with a maximum value of $53 \pm 40 \mathrm{IU} / \mathrm{ml}$ (fig. 2b). Then, a decrease of the values of anti-IA2 autoantibodies was observed at the age of 13 years and 15 years with the respective titers of $40.03 \pm 7.98 \mathrm{IU} / \mathrm{ml}$ and $13.40 \pm 2.65 \mathrm{IU}$ / $\mathrm{ml}$ (Figure 2B).

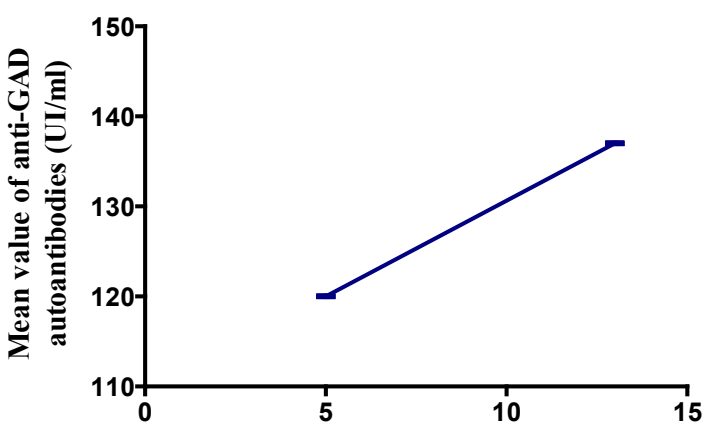

Age of sibling of T1D (Year)

A

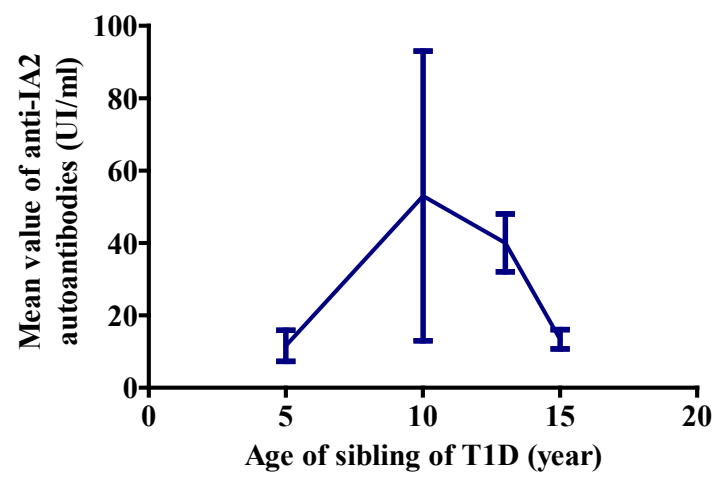

B

Figure 2. (Part A and Part B): Mean value of anti-GAD and anti-IA2 autoantibodies according to the age of type $1 \mathrm{~A}$ diabetic siblings

\section{Discussion}

The results showed that glutamic acid decarboxylase autoantibodies (anti-GAD) and phosphatase autoantibodies IA2 (anti-IA2) were present in T1D and their siblings with a significant difference $(p<0.0001 ; p=0.0021<0.05)$. Islet cells autoantibodies were present in a single T1D and absent in siblings. These results show that T1D who developed these autoantibodies are actually T1D. Indeed, type 1A diabetes is an autoimmune disease due to the destruction of pancreatic islet $\beta$-cells by $T$ cells. These results corroborate those of Delic-Sarac et al. [10], who found anti-GAD and anti-IA2 autoantibodies in the diabetic patient's serum. The presence of these autoantibodies in siblings of T1D shows that they constitute a population at risk for diabetes, as Siljander et al. 
[12], De Grijse et al. [13] and Simonen-Tikka et al. [20], showed in their study. Anti-ICA, anti-GAD and anti-IA2 auto-antibodies are very important markers for screening for type $1 \mathrm{~A}$ diabetes.

The peak of anti-GAD autoantibodies observed at 9 years old $(604.30 \pm 521.70 \mathrm{IU} / \mathrm{ml})$ and the peak of anti-IA2 autoantibodies observed at the age of 10 years $(125.10 \pm 90.10 \mathrm{IU} / \mathrm{ml})$ in T1D show that the autoimmune reaction in these patients is maximal. Thereby, the body produces a large amount of anti-GAD and anti-IA2 autoantibodies directed against glutamic acid decarboxylase and tyrosine phosphatase IA2 located in pancreatic $\beta$-cells. The age of 9 years old would be the favorable age for the production of anti-GAD autoantibodies and the age of 10 years old would be the favorable age for the production of anti-IA2 autoantibodies in T1D in Côte d' Ivoire. These results corroborate those of Boitard and Mallone [7].

In siblings, the peak of anti-GAD autoantibodies observed at 13 years old $(137 \mathrm{IU} / \mathrm{ml})$ and the peak of anti-IA2 autoantibodies observed at 10 years old $(53 \pm 40$ $\mathrm{IU} / \mathrm{ml}$ ) show that these patients constitute a population at risk for diabetes. These results show that the autoimmune reaction in siblings of TD1 has started. Thereby, at 13 and 10 years old their organs produce a large amount of anti-GAD and anti-IA2 autoantibodies directed against glutamic acid decarboxylase and tyrosine phosphatase IA2 located in pancreatic $\beta$-cells. These patients should be followed to avoid the installation of clinical diabetes. 13 years old and 10 years old would be favorable for the production of anti-GAD and anti-IA2 in siblings of T1D in Côte d'Ivoire. These results corroborate those of Andrea et al. [21], in a cohort study shown that the age of appearance of autoantibody was a major determinant of the age at diabetes diagnosis, accounting for $47 \%$ of the variance $(r=$ $0.69, \mathrm{P}<0.0001)$. The mean age of appearance of first autoantibody varied by group: $6.1,5.5$, and 3.8 years for one, two, or three antibodies, respectively $(\mathrm{P}=0.0007)$.

\section{Conclusions}

This study showed the importance of searching diabetes autoantibodies in T1D and their siblings in Côte d'Ivoire. In fact, these autoantibodies constitute an important classification criterion for diabetes and a marker for early detection of diabetes in siblings of T1D. Indeed, anti-GAD and anti-IA2 autoantibodies are produced in large quantities in T1D at the respective ages of 9 years old and 10 years old. In siblings, anti-GAD and anti-IA2 autoantibodies are produced in large quantities at the respective ages of 13 years old and 10 years old. This could explain the high mortality rate among young T1Ds. This research will allow a biological application of diabetes autoantibodies to improve the diabetes care in Côte d'Ivoire.

\section{Acknowledgment}

We thank the Laboratory of Biochemistry-Pharmacody namics, Faculty of Biosciences, Felix Houphouët Boigny University, for allowing us to do this work. We thank Professor Hatem Masmoudi, head of service of Laboratory of Immunology, Hospital Habib Bourguiba of Sfax, Tunisia, for the realization of diabetes autoantibodies.

\section{REFERENCES}

[1] Vieira A., N. Druelle, M. Courtney, F. Avolio, and N. Ben-Othman, A. Pfeifer, E. Gjernes, B. Faurite and P. Collombat. Reprogramming pancreatic cells to $\beta$ cells. Medecine Sciences, 2013; 29: 749-755.

[2] IDF (International Diabetes Federation), 2013- Available at: http://www.idf.org/diabetesatlas.

[3] Agbre-Yace, M. L., E. E. Oyenusi, A. O. Oduwole, M. D. Ake and J. R. Abodo. Prevalence of diabetes mellitus among children and adolescents in the district of Abidjan in Cote d'Ivoire: a population based study. J Diabetes Metab Disord, 2016, 15:38

[4] Faideau, B., E. Larger, F. Lepault, J. C. Carel and C. Boitard. Role of beta-cells in type 1 diabetes pathogenesis. Diabetes, 2005, 54 (Suppl. 2): S87-S96.

[5] Carel, J.C. and C. Boitard. Pathogénie du diabète de type 1. Option/Bio, Le cahier Scientifique, 1998, 218(suppl) : 9-11.

[6] Chauffert, M., D. Chevenne and M. Noël. Dépistage et prédiction du diabète de type 1. Option/Bio, Le cahier Scientifique, 1998, 218(suppl) : 14-18.

[7] Boitard C. and R. Mallone. Diabète de type 1: vers de nouveaux biomarqueurs. Médecine-sciences flammarion/lavoisier - actualités néphrologiques, 2010 : $31-41$.

[8] Boerschmann, H., M. Walter, P. Achenbach and A.G. Ziegler. Survey of recent clinical trials of the prevention and immunointervention of type 1 diabetes mellitus. Dtsch med Wochenschr, 2010, 135: 350-354.

[9] Ziegler, A. G., M. Pflueger, C. Winkler, P. Achenbach, A. Beena, J. P. Krischer and E. Bonifacio. Accelerated progression from islet autoimmunity to diabetes is causing the escalating incidence of type 1 diabetes in young children. J Autoimmun, 2011, 37(1): 37.

[10] Delic-Sarac, M., S. Mutevelic, J. Karamehic, D. Subasic, T. Jukic, J. Coric, O. Ridjic, M. Panjeta and L. Zunic. ELISA Test for Analyzing of Incidence of Type 1 Diabetes Autoantibodies (GAD and IA2) in Children and Adolescents. Acta Inform Med, 2016, 24(1): 61-65.

[11] Bouhours-Nouet N. and R. Coutant. Clinique et diagnostique du diabète de type 1. EMC-Pédiatrie, 2005, 2: 220-242.

[12] Siljander, H. T., R. Veijola, A. Reunanen, S. M. Virtanen, H. K. Åkerblom and M. Knip. Prediction of type 1 diabetes among siblings of affected children and in the general population. Diabetologia, 2007, 50: 2272-2275. 
[13] De Grijse, J., M. Asanghanwa, B. Nouthe, N. Albrecher, P. Goubert, I. Vermeulen, S. Van Der Meeren, K. Decochez, I. Weets, B. Keymeulen, V. Lampasona, J. Wenzlau, J. C. Hutton, D. Pipeleers and F. K. Gorus. Predictive power of screening for autoantibodies against insulinoma-associated protein 2 beta (IA-2B) zinc transporter -8 to select first degree relatives of type 1 diabetic patients with risk of rapid progression to clinical onset of the disease-implication for prevention trials. Diabetologia, 2010, 53(3): 517-524.

[14] Baekkeskov, S., H. J. Aanstoot, S. Christgai, A. Reetz, M. Solimena, M. Cascalho, F. Folli, H. Richter-Olesen and P. De Camilli. Identification of the $64 \mathrm{~K}$ autoantigen in insulin-dependent diabetes as the GABA-synthesizing enzyme glutamic acid decarboxylase. Nature, 1990, 347:151-156.

[15] Hayakawa, N., L. D. Premawardhana, M. Powell, M. Masuda, C. Arnold, J. E. M. Sanders, S. Chen, J. C. Jaume, S. Baekkeskov, B. R. Smith and J. Furmaniak. Isolation and characterization of human monoclonal auto-antibodies to glutamic acid decarboxylase. Autoimmunity, 2002, 35(5): 343-342.

[16] Genovese, S., E. Bazzigaluppi, D. Goncalves, A. Ciucci, M. G. Cavallo, F. Purrelo, M. Anello, C. M. Rotella, G. Bardini, O. Vaccaro, G. Riccardi, P. Travaglini, E. Morenghi, E. Bosi and P. Pozzilli. Clinic phenotype and beta-cell autoimmunity in Italian patients with adult-onset diabetes. Eur J Endocrinol, 2006, 154: 441-447.
[17] Achenbach P., V. Lampasona, U. Landherr, K. Koczwara, S. Krause, H. Grallert, C. Winkler, M. Pflüger, T. Illig, E. Bonifacio and A.G. Ziegler. Autoantibodies to zinc transporter 8 and SLC30A8 genotype stratify type 1 diabetes risk. Diabetologia, 2009, 52(9): 1881- 1888.

[18] Warncke K., E. E. Fröhlich-Reiterer, A. Thon, S. E. Hofer, D. Wiemann and R. W. Holl. Polyendocrinopathy in children, adolescents, and young adults with type 1 diabetes: a multicenter analysis of 28,671 patients from the German/Austrian DPV-Wiss database. Diabetes care, 2010, 33: 2010-2012.

[19] Yu L., Y. Liu, D. Miao, J. Wenzlau, H. Davidson, J. Hutton and G. S. Eisenbarth. Triple chimeric islet auto-antigen IA2-Znt8WR to facilitate islet autoantibody determination. J Immunol Methods, 2010, 353: 20-23.

[20] Simonen-Tikka M. L., M. Pflueger, P. Klemola, C. Savolainen-Kopra, T. Smura, S. Hummel, S. Kaijalainen, K. Nuutila, O. Natri, M. Roivainen and A. G. Ziegler. Human enterovirus infection in children at increased risk for type 1 diabetes: the babydiet study. Diabetologia, 2011, 54: 2995-3002.

[21] Andrea K. S., J. Kelly, J. B. Katherine, M. Dongmei, Y. Liping, C. H. John, S. E. Eisenbarth and J. R. Marian. Age of Islet Autoantibody Appearance and Mean Levels of Insulin, but Not GAD or IA-2 Autoantibodies, Predict Age of Diagnosis of Type 1 Diabetes. Diabetes Autoimmunity Study in the Young. Diabetes Care, 2011, 34: 1397-1399. 